\title{
Moisture Sensitivity, Optical, Mechanical and Structural Properties of Whey Protein-Based Edible Films Incorporated with Rapeseed Oil
}

\author{
Sabina Galus* and Justyna Kadzińska \\ Department of Food Engineering and Process Management, Faculty of Food Sciences, \\ Warsaw University of Life Sciences-SGGW (WULS-SGGW), 159c Nowoursynowska St., \\ PL-02-776 Warsaw, Poland \\ Received: September 5, 2014 \\ Accepted: October 21, 2015
}

\begin{abstract}
Summary
The objective of this work is to study the effect of the rapeseed oil content on the physical properties of whey protein emulsion films. For this purpose, whey protein films with the addition of $0,1,2$ and $3 \%$ of rapeseed oil, and glycerol as a plasticizer were obtained by the casting method. Film-forming emulsions were evaluated and compared using light scattering granulometry. The Sauter mean diameters $\left(d_{32}\right)$ of lipid droplets in film-forming solutions showed an increasing trend when increasing the oil volume fractions. The inclusion of rapeseed oil enhanced the hydrophobic character of whey protein films, reducing moisture content and film solubility in water. All emulsified films showed high lightness $\left(L^{*} \approx 90\right)$. Parameter $a^{*}$ decreased and parameter $b^{*}$ and total colour difference $(\Delta E)$ increased with the increase of the volume fractions of oil. These results were consistent with visual observations; control films were transparent and those containing oil opaque. Water vapour sorption experimental data at the full range of water activity values from 0.11 to 0.93 were well described with Peleg's equation $\left(R^{2} \geq 0.99\right)$. The tensile strength, Young's modulus and elongation at break increased with the increase of rapeseed oil volume fraction, which could be explained by interactions between lipids and the protein matrix. These results revealed that rapeseed oil has enormous potential to be incorporated into whey protein to make edible film or coating for some food products. The mechanical resistance decreased with the addition of the lipids, and the opacity and soluble matter content increased.
\end{abstract}

Key words: edible films, whey protein, rapeseed oil, emulsion, water vapour sorption

\section{Introduction}

Biopolymers from various natural resources such as proteins and polysaccharides have been considered attractive alternatives for non-biodegradable petroleum-based materials (1). Proteins are similar to polysaccharides in their ability to form films characterized by mechanical and barrier properties. They are abundant, renewable, environmentally friendly, and biodegradable, and could be an alternative resource of bioplastics in packaging applications. Edible films and coatings can also help to maintain moisture, thereby improving shelf life of coated products based on their good film-forming capacities.

Protein-based edible films have interesting properties, and various materials have been tested including wheat gluten (2), whey protein (3), soya protein (4), casein (5), collagen (6), gelatin (7), corn zein (8), egg white proteins (9), quinoa (10), myofibrillar proteins (11) and other proteins (12). Milk proteins, such as whey proteins, have special properties that make them highly suitable for obtaining edible films. Their excellent nutritional value and numerous functional properties such as solubility in wa- 
ter and ability to act as emulsifiers are important factors for the formation of edible films.

Whey proteins are edible, biodegradable, originating from the waste stream from the cheese industry, with interesting mechanical properties $(13,14)$. The film-forming properties of whey proteins enable the production of transparent, flexible, colourless and odourless edible films. Such films are usually obtained by casting and drying of aqueous whey protein isolates (15).

Proteins, as well as polysaccharides, form films with good mechanical properties but they are poor moisture barriers, because of their hydrophilic nature. Lipids can be incorporated into a hydrocolloid matrix either by the formation of bilayer films or dispersing a lipid in the hydrocolloid aqueous solution to obtain an emulsified film that requires only one film-forming emulsion casting and a single drying process $(1,16)$. Generally, lipids act as a good moisture barrier (17) and also induce development of a heterogeneous film structure featuring discontinuities in the polymer network (5). Therefore, hydrocolloid-lipid composite films have good water vapour barrier capacity and the properties of the films have been reported to be dependent on the type and quantity of components.

Lipids of different types (fats and oils) have been successfully incorporated into protein-based edible films. Ma et al. (1) prepared gelatin films with olive oil incorporated by the microfluidic emulsification technique, having good water and ultraviolet light barrier properties. Barrier, optical and mechanical properties of soya protein-based edible films were modified with lactic acid and oil (soybean and olive oil) (18) or oleic acid and beeswax mixtures (19). Improved mechanical properties of composite sodium caseinate films modified with tung oil addition were obtained by Pereda et al. (20). Protein and lipid ingredients may interact favourably, resulting in edible films with improved structural and functional properties.

Properties of protein-lipid composite edible films depend not only on the compounds used in the polymer matrix but also on their compatibility and preparation techniques. In literature, there is little information about using rapeseed oil in preparation of edible films or coatings. Furthermore, a previous study (21) concerning whey protein films modified with the emulsion of rapeseed oil showed that the emulsion structure in the film-forming solution changed significantly during drying, with the occurrence of oil creaming and coalescence. The film thickness decreased significantly with the emulsion present in the film-forming solution. Thus, the objective of this work is to obtain whey protein isolate/rapeseed oil-emulsified films with constant film thickness, but without preparing and mixing two solutions (film-forming and rapeseed oil emulsion). The effects of rapeseed oil content on lipid droplet distribution, film solubility in water, swelling index, sorption, optical and mechanical properties were measured. In addition, the effect of temperature on moisture sorption isotherms was analyzed and film microstructure was monitored.

\section{Materials and Methods}

\section{Materials}

A BiPro whey protein isolate ( $\sim 90 \%$ protein) was obtained from Davisco Foods International Inc. (La Sueur,
MN, USA). Rapeseed oil was supplied by a local shop and was produced by ZP Kruszwica S.A. (Kruszwica, Poland). Anhydrous glycerol, phosphorous pentoxide and thymol were purchased from POCH S.A. (Gliwice, Poland). Salts to prepare saturated solutions to control the water activity $\left(a_{\mathrm{w}}\right)$ for the determination of water vapour sorption isotherms, including lithium chloride, potassium acetate, magnesium chloride, potassium carbonate, magnesium nitrate, sodium bromide, sodium chloride and potassium chloride were supplied by POCH S.A.

\section{Preparation of film-forming emulsions}

Film-forming solutions were prepared according to the modified method described in a previous study (21) by slowly dissolving $8 \%$ (by mass) whey protein isolate in distilled water under constant magnetic stirring (RTC basic IKAMAG ${ }^{\mathrm{TM}}$; IKA, Staufen, Germany) at $250 \mathrm{rpm}$ for $10 \mathrm{~min}$. The $\mathrm{pH}$ value of the solutions was 7 and it did not need to be adjusted. No additional salts were added. Subsequently, the solutions were heated on a magnetic plate at $(80 \pm 1){ }^{\circ} \mathrm{C}$ for $30 \mathrm{~min}$ to denature the whey protein, then they were cooled down to room temperature and $50 \%$ (by mass) glycerol was added to plasticize the films. Rapeseed oil at 1, 2 or $3 \%$ volume fraction was homogenized with whey protein isolate solution at $13500 \mathrm{rpm}$ with Ultra Turrax (IKA Yellowline DI25 basic, IKA) for 6 min to give the emulsions. The film-forming solutions were prepared and used immediately every time they were required.

\section{Particle size measurements}

Film-forming solution structure was determined by laser light scattering granulometry using a Malvern Mastersizer Hydro 2000 SM instrument (Malvern Instruments Ltd., Worcestershire, UK) at room temperature. Reproducibility was tested by carrying out three measurements of each replicate. The measured Sauter mean diameter $d_{32}$ is the diameter of a hypothetical spherical particle that represents the total number of particles in the sample. It also represents the average size based on the specific surface per unit of volume. This mean particle diameter is defined according to Kokoszka et al. (21) as follows:

$$
d_{32}=\sum n_{\mathrm{i}} d_{\mathrm{i}}^{3} / \sum n_{\mathrm{i}} d_{\mathrm{i}}^{2}
$$

where $n_{\mathrm{i}}$ is the number of droplets in each size class and $d_{\mathrm{i}}$ is the droplet diameter. The specific surface corresponds to the developed area of dispersed oil globules normalized by the volume of lipid phase, expressed in $\mathrm{m}^{2} / \mathrm{mL}$.

\section{Film preparation}

Film-forming emulsions were poured onto a series of Petri dishes. To control film thickness, the volume of each film-forming suspension poured onto a plate with surface area of $148 \mathrm{~cm}^{2}$ was the same, $15 \mathrm{~mL}$. The film-forming suspensions were dried at $(25 \pm 1){ }^{\circ} \mathrm{C}$ and $(50 \pm 1) \%$ relative humidity $(\mathrm{RH})$ in a ventilated chamber (model KBF 720; Binder, Tuttlingen, Germany) for $24 \mathrm{~h}$. The dried suspensions formed easily detachable films with the final thickness of $(70 \pm 5) \mu \mathrm{m}$. Then, the films were peeled off and conditioned again at $(53 \pm 1) \% \mathrm{RH}$ and $(25 \pm 1){ }^{\circ} \mathrm{C}$ for $48 \mathrm{~h}$ prior to testing. 


\section{Film thickness measurement}

Film thickness was measured with an electronic gauge model Ultrametr A400 (Metrison Sp. z.o.o., Mościska, Poland) with a precision of $1 \mu \mathrm{m}$. The electronic gauge was calibrated at 74 and $139 \mu \mathrm{m}$ using standards prior to film thickness measurements. Five thickness measurements of each film were taken, one of the centre and four around the perimeter, and the average was used in the calculations (22).

\section{Determination of moisture content}

Moisture content was determined by the mass loss of $1 \mathrm{~g}$ of film after $24 \mathrm{~h}$ of oven drying at $(105 \pm 1)^{\circ} \mathrm{C}$, and expressed as the percentage of initial film mass loss during drying (23). Three repetitive analysis of each film were made and the results were expressed as mean value \pm standard deviation.

\section{Film solubility in water}

To determine the water resistance of whey protein films with incorporated rapeseed oil, water solubility of each film was measured in at least five repetitions according to the method of Rhim et al. (23). Five randomly selected samples $(20 \mathrm{~mm} \times 20 \mathrm{~mm})$ of each type of film were first dried at $(105 \pm 1){ }^{\circ} \mathrm{C}$ for $24 \mathrm{~h}$ to determine initial dry matter. The film specimens were placed in a $50-\mathrm{mL}$ beaker containing $30 \mathrm{~mL}$ of distilled water. After sealing the beaker mouth with aluminum foil, the beakers were placed in an environmental chamber at $25^{\circ} \mathrm{C}$ for $24 \mathrm{~h}$ with occasional gentle stirring. Unsolubilized dry matter was determined by removing the film pieces from the beakers, gently rinsing them with distilled water, and then oven drying at $(105 \pm 1)^{\circ} \mathrm{C}$ for $24 \mathrm{~h}$. The amount of dry matter dispersed in water after $24 \mathrm{~h}$ of immersion was obtained by subtracting the mass of undispersed dry matter from the mass of the initial dry matter and expressed in percentage.

\section{Determination of swelling index}

The swelling index of films was determined using the modified method described by Cao et al. (24). The films were cut into pieces of $20 \mathrm{~mm} \times 20 \mathrm{~mm}$, air-dried and weighed. They were then immersed in distilled water for $2 \mathrm{~min}$ at $25^{\circ} \mathrm{C}$. Wet samples were wiped with filter paper to remove excess liquid and weighed. The amount of absorbed water was calculated by subtracting the initial mass of air-dried films from the mass of the wet samples and expressed in percentage. The measurement was repeated at least five times for each type of film and was expressed as mean value \pm standard deviation.

\section{Opacity}

Films were cut into rectangular pieces $1 \mathrm{~cm} \times 4 \mathrm{~cm}$ and directly placed in a UV/Vis Helios Gamma spectrophotometer test cell (Thermo Fisher Scientific, Waltham, MA, USA) using an empty test cell as the reference. The opacity of the films was calculated by the following equation (25):

$$
\text { Opacity }=A_{600 \mathrm{~nm}} / \delta
$$

where $A_{600 \mathrm{~nm}}$ is the value of absorbance at $600 \mathrm{~nm}$ and $\delta$ is the film thickness in $\mathrm{mm}$. The measurements were repeated at least five times.

\section{Colour determination}

Colour of films on the surface was determined with a colourimeter model CR-300 (Konica Minolta, Tokyo, Japan) using the CIELab colour parameters. $L^{*}, a^{*}$ and $b^{*}$ values were averaged from ten readings across for each sample and total colour difference $(\Delta E)$ was calculated according to the following equation (26):

$$
\Delta E=\sqrt{\left(\Delta L^{*}\right)^{2}+\left(\Delta a^{*}\right)^{2}+\left(\Delta b^{*}\right)^{2}}
$$

where $\Delta L^{*}, \Delta a^{*}$ and $\Delta b^{*}$ are the differentials between a sample colour parameter and the colour parameter of a standard $\left(L^{*}=91.5, a^{*}=1.01, b^{*}=2.20\right)$ used as the film background.

\section{Water vapour sorption isotherms}

Film samples $(20 \mathrm{~mm} \times 20 \mathrm{~mm})$ were pre-dried for 7 days over phosphorous pentoxide $\left(\mathrm{P}_{2} \mathrm{O}_{5}\right)$ to reduce the initial moisture content. Then they were placed in separate desiccators to obtain the desired water activities from 0.114 to 0.934 at 5 and $25^{\circ} \mathrm{C} \mathrm{(27)} \mathrm{using} \mathrm{the} \mathrm{following} \mathrm{satu-}$ rated salt solutions: $\mathrm{LiCl}, \mathrm{CH}_{3} \mathrm{COOK}, \mathrm{MgCl}_{2}, \mathrm{~K}_{2} \mathrm{CO}_{3}$, $\mathrm{Mg}\left(\mathrm{NO}_{3}\right)_{2}, \mathrm{NaBr}, \mathrm{NaCl}$ and $\mathrm{KCl}$. The samples were removed from the desiccators and weighed after incubation for 10 days (preliminary experiments determined that the samples reached a constant mass after approx. 7 days). Equilibrium moisture content was calculated from the increase in the mass of the dried sample after equilibration at a given RH. Under the above conditions, a period of 7 days was sufficient to establish moisture equilibrium. Thymol as a fungistatic substance was used in desiccators with water activity above 0.75 to avoid microbial growth. Adsorption tests were done in triplicate at 5 and $25^{\circ} \mathrm{C}$. The experimental moisture sorption data were averaged and fitted using Peleg's equation (28) as follows:

$$
w=\mathrm{A} \cdot a_{\mathrm{w}}^{\mathrm{B}}+\mathrm{C} \cdot a_{\mathrm{w}}^{\mathrm{D}}
$$

where $w$ is the equilibrium moisture content expressed in $\mathrm{g}$ of water per $\mathrm{g}$ of dry mass, and A-D are the equation constants at the water activity $a_{\mathrm{w}}$. Peleg's equation parameters were calculated using the program TableCurve 2D v. 3 for Windows (Jandel Scientific Software, San Rafael, CA, USA).

\section{Determination of mechanical properties}

Tensile strength (TS), Young's modulus (YM) and elongation at break $\left(\varepsilon_{\mathrm{b}}\right)$ of the films $25 \mathrm{~mm} \times 100 \mathrm{~mm}$ in size were determined using a Texture Analyzer TA-XT2i (Stable Microsystems, Haslemere, UK) according to the ASTM standard method D882-02 (29). The film specimens were mounted in the self-tightening roller grips of the testing machine and stretched at the rate of $1 \mathrm{~mm} / \mathrm{s}$ until breaking. The initial distance of separation was adjusted to $50 \mathrm{~mm}$ (22). The analysis was made at ambient temperature and relative humidity of $(50 \pm 5) \%$. At least ten replicates of each film formulation were tested. YM was evaluated as the slope of the initial linear portion of stress-strain 
curves. The TS and $\varepsilon_{\mathrm{b}}$ were calculated according to the following equations (10):

$$
\mathrm{TS}=F / A_{\mathrm{i}}
$$

where $F$ (in $\mathrm{N}$ ) is the maximum force at rupture of the film and $A_{\mathrm{i}}\left(\right.$ in $\mathrm{mm}^{2}$ ) is the initial cross-sectional area of the films, and

$$
\varepsilon_{\mathrm{b}}=\left[\left(l_{\mathrm{f}}-l_{\mathrm{i}}\right) / l_{\mathrm{i}}\right] \cdot 100
$$

where $l_{\mathrm{f}}$ is the final distance at elongation at break (in $\mathrm{mm}$ ) and $l_{\mathrm{i}}$ is the initial distance between the grips.

\section{Scanning electron microscopy}

Film microstructure was observed under a scanning electron microscope (Quanta 200; FEI, Brno, Czech Republic). A $5 \mathrm{~mm} \times 5 \mathrm{~mm}$ sample was fixed on the support using silver paste at an angle of $90^{\circ}$ to the surface, which allowed observation of the cross section of the film (22). Films were observed at a magnification of $500 \times$ (surfaces) and $1500 \times$ (cross sections).

\section{Statistical analysis}

Statistical analysis was performed with STATISTICA v. 10.0 software (StatSoft Inc., Tulsa, OK, USA). The analysis of variance (ANOVA) was performed with post hoc Tukey's test to detect significant differences in film properties. The significance level used was 0.05 . The adequacy of the fitted Peleg's equation was evaluated by determining the coefficient $\mathrm{R}^{2}$ using the following equation:

$$
\mathrm{R}^{2}=\sum_{i=1}^{\mathrm{n}}\left(w_{\mathrm{p}}-\bar{w}_{\mathrm{e}}\right)^{2} / \sum_{i=1}^{\mathrm{n}}\left(w_{\mathrm{e}}-\bar{w}_{\mathrm{e}}\right)^{2}
$$

where $n$ is the number of observations, $w_{\mathrm{p}}$ is the predicted moisture content), $\bar{w}_{\mathrm{e}}$ is average water content and $w_{\mathrm{e}}$ is experimental water content, all expressed in $g$ of water per g of dry mass.

\section{Results and Discussion}

Lipid incorporation is hindered at high oil contents (30) and the formation of the stable emulsion films often requires addition of emulsifier agents, e.g. arabic gum. Thus, whey protein films were prepared with $0,1,2$ and $3 \%$ of rapeseed oil, which is less than the literature findings for other hydrocolloid films with the volume fraction of up to $20 \%$ of liquid oil $(1,20,31,32)$. Oil types that are liquid at room temperature favour both the reduction of the droplet size during emulsification and the roundness of the droplets. The low lipid content favoured its incorporation in the protein dispersion (33). Films prepared with oil were more flexible and stretchable than control films, probably due to the plasticizing effect of rapeseed oil. Similar behaviour was observed by other authors $(31,34)$ working with protein films incorporated with lipids.

\section{Particle size distribution}

The particle size of the lipid droplets distributed in the dried emulsified films is important in understanding their functional properties (35) and has been previously reported $(1,21)$. The film-forming solutions produced by whey protein with 1, 2 and $3 \%$ of rapeseed oil showed a bimodal particle size distribution, and two maxima occurred close to 1.66 and $8.71 \mu \mathrm{m}$ in the volume distribution (Fig. 1). The two maxima shifted towards lower lipid droplet size in film-forming solution containing $3 \%$ of rapeseed oil in comparison with the two other solutions. The particle size distribution of the film-forming solutions was dependent on the rapeseed oil volume fraction. Bimodal particle size distribution and droplet size ranging from 0 to $11 \mu \mathrm{m}$ were observed by Ma et al. (1) in gelatin film-forming solutions with olive oil. Atarés et al. (33) observed wide and multimodal lipid droplet distribution in sodium caseinate solution incorporated with cinnamon and ginger essential oils. Some of the small dispersed lipid particles may be susceptible to flocculation due to the incomplete coating on the interfacial surface with the stabilizing polymer (whey protein), with subsequent formation of a big lipid droplet peak (1). The bigger lipid particles in protein solution may also be attributed to the self-aggregation of the protein (36). Pérez-Gago and Krochta (30) used light scattering analysis to obtain the size distribution of whey protein isolate solution without lipid addition as a function of $\mathrm{pH}$. They observed that the particle size distribution for pure whey protein solution was very similar to that for the same solution incorporated with beeswax at $\mathrm{pH}=5$, indicating that the particle size of emulsions was probably due to protein aggregation.

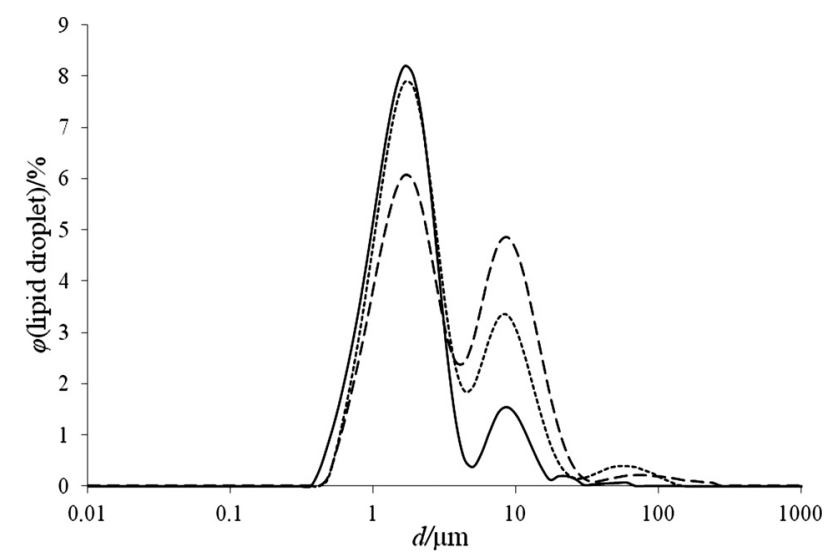

Fig. 1. Particle size distribution in whey protein film-forming emulsions with different volume fraction of rapeseed oil $(-1$ $\%, \cdots . . .2 \%$ and ---- $3 \%$ )

Table 1 shows the results of Sauter mean diameter $\left(d_{32}\right)$ of the film-forming emulsions. The oil droplet diameter increased with increasing rapeseed oil content, which was also observed when testing carrageenan films with lipids (35) and films incorporated with essential oils based on sodium caseinate $(33)$ and chitosan $(37,38)$. This tendency is in contrast with the results obtained in a previous study when rapeseed oil was added to whey protein solution as a separate emulsion (21). Similarly, a reduction tendency after increasing the amount of oil was observed by Ma et al. (1) in gelatin films containing olive oil at higher volume fractions (5-20\%). Increasing Sauter mean diameter $\left(d_{32}\right)$ of film-forming solutions after increasing the volume fraction of oil may be linked to the different balance of interaction forces between the solvent and protein, and 
Table 1. Sauter mean diameter of oil particles $\left(d_{32}\right)$, moisture content, film solubility in water, and swelling index of whey protein films with different volume fractions of rapeseed oil

\begin{tabular}{ccccc}
\hline$\varphi$ (rapeseed oil) $/ \%$ & $d_{32} / \mu \mathrm{m}$ & $w$ (water)/\% & Film solubility in water/\% & Swelling index/\% \\
\hline 0 & - & $(17.9 \pm 1.4)^{\mathrm{a}}$ & $(42.4 \pm 0.2)^{\mathrm{c}}$ & $(51.60 \pm 0.01)^{\mathrm{a}}$ \\
1 & $(1.96 \pm 0.06)^{\mathrm{a}}$ & $(17.5 \pm 1.6)^{\mathrm{a}}$ & $(40.9 \pm 0.3)^{\mathrm{b}}$ & $(55.30 \pm 0.01)^{\mathrm{c}}$ \\
2 & $(2.07 \pm 0.01)^{\mathrm{b}}$ & $(17.2 \pm 0.6)^{\mathrm{a}}$ & $(40.7 \pm 0.2)^{\mathrm{b}}$ & $(53.30 \pm 0.01)^{\mathrm{b}}$ \\
3 & $(2.42 \pm 0.03)^{\mathrm{c}}$ & $(16.8 \pm 0.5)^{\mathrm{a}}$ & $(37.4 \pm 1.7)^{\mathrm{a}}$ & $(52.40 \pm 0.01)^{\mathrm{ab}}$ \\
\hline
\end{tabular}

The results are expressed as mean values with standard deviations. Different letters in superscript within the same column indicate significant differences between the films $(p<0.05)$

solvent and rapeseed oil components as a function of oil-to-protein ratio (33). Therefore, the lipid droplet size and distribution in hydrocolloid film-forming solutions may depend on lipid type and amount. The droplet size of rapeseed oil in the emulsions was in the range of 1.96$2.42 \mu \mathrm{m}$. These values are higher than those obtained in whey protein with soya oil solution, $0.017-0.37 \mu \mathrm{m}$ (31), and similar to those observed for other film-forming solutions containing vegetable oils, e.g. gelatin with olive oil, 0.36-6.6 $\mu \mathrm{m}(1)$, or hydroxypropyl methylcellulose with sunflower oil, 1.5-14.5 $\mu \mathrm{m}$ (39).

\section{Film solubility}

Resistance of edible films to water is desirable if the film is to be used for the preservation of intermediate- or high-moisture foods. A film with poor water resistance will dissolve quickly causing an increase in the diffusion of the components from the surface to the bulk of the food, resulting in a low protective effect at the food surface (40). Potential application may require water insolubility to enhance product integrity and water resistance. In some cases film water solubility before the consumption of the product might be beneficial (41).

Whey protein films with rapeseed oil did not dissolve and did not have visual loss in integrity or break apart after they were immersed into water and dried for $24 \mathrm{~h}$. This is due to the highly stable protein network. The water solubility of pure whey protein film was $42.4 \%$ and was reduced to $37.4 \%$ when $3 \%$ of rapeseed oil were added (Table 1). These values are similar to other pure edible biopolymer films or those containing lipids, as follows: $13.6-34.4 \%$ of whey protein and beeswax films dried at $25{ }^{\circ} \mathrm{C}(42), 42.3-69.9 \%$ of galactomannan and chitosan films (43), 22.4-39.4\% of whey protein and beeswax films dried at $5{ }^{\circ} \mathrm{C}(44)$, and $27.5-43.1 \%$ of cassava starch films containing carnauba wax and stearic acid (45). The relatively low solubility of whey protein films in water has been previously reported and could be explained by the high interaction and presence of intermolecular disulphide bonds as a result of the heat treatment (46). Pérez-Gago et al. (41) confirmed that native protein films are soluble in water, but the films obtained from denatured whey protein solution are relatively insoluble. Increasing the volume fraction of rapeseed oil in the films increases the resistance of films to water. This means that the addition of a hydrophobic substance to the film formulation produces films with high water resistance. All films contain glycerol and its plasticizing effect might interact with water and interrupt the film network with hydrogen bonds, reducing the cohesiveness of whey protein matrix and increasing solubility in water. However, rapeseed oil incorporation to whey protein matrix plasticized with glycerol caused the decrease in water solubility indicating that lipid compounds may interact also with glycerol, therefore limit film affinity to water. On the other hand, films containing oil have more irregular microstructure in which oil droplets are dispersed and have impact on film hydrophobicity. Previous works have reported that the solubility of biodegradable films is influenced by the plasticizer type and its volume fraction used in the film-forming solutions (47). Razavi et al. (48) noticed that increasing the volume fraction of plasticizers (glycerol or sorbitol) from 40 to $100 \%$ affected an increase of water solubility in sage seed gum films. Similar observations were found by Ahmadi et al. (49) in psyllium seed films plasticized with glycerol at the volume fraction from 15 to $35 \%$.

\section{Swelling capacity of films}

Swelling capacity of edible films indicates their biodegradation and applicability in packaging food with high water content such as peeled fruits (43). The effect of rapeseed oil addition on the swelling index is shown in Table 1. The high value of swelling is due to the hydrophilic characteristic of whey protein films. Nevertheless, from our observation, all films did not break even after the swelling index study, which is the result of film water resistance. During the swelling index study, it was noticed that the films in contact with water started softening before an increase in swelling, which then began to decrease when the film started to dissolve. With the addition of $1 \%$ of rapeseed oil the values of the swelling index of whey films increased from 51.60 to $55.30 \%$ and decreased to $52.40 \%$ when increasing the volume fraction of oil to $3 \%$. The higher degree of swelling of the film with the addition of oil may be related to the modification of microstructure during drying. Lipid droplets change the internal structure of films, leading to migration of water molecules, and with increasing volume fraction of lipids, the swelling decreases because of their hydrophobic character. The high volume fraction of oil changes the properties of the films, decreasing the affinity for water. Di Pierro et al. (50) also reported that the degree of swelling of a polymeric material strongly depends on the amount and nature of intermolecular chain interactions. The decrease of the values of swelling index or film solubility in whey protein films with the addition of oil can be explained by the diminution of the hydrophilic portion of the film $(43,51)$, which reduces its affinity for water molecules. 


\section{Colour and opacity of films}

The transparency of edible films is a key to good acceptance by consumers since it has a direct impact on the appearance of the coated product $(22,52)$. The transparency of emulsion-based films is related to their internal structure, which is affected by the oil volume fraction and droplet size distribution in film-forming emulsions and its rearrangement during drying (53). Solvent evaporation during drying induces changes in the emulsion structure by destabilization phenomena such as creaming, aggregation and/or coalescence, which have an important role in the optical properties of emulsion-based edible films (39). Thus, to better understand optical properties of whey protein films with rapeseed oil, colour parameters $L^{*}, a^{*}, b^{*}$ and film opacity were analyzed, and total colour difference $(\Delta E)$ caused by lipid addition was determined. Table 2 shows the values of these optical parameters of all studied films. As can be observed, all the films have high lightness ( $L^{*}$ parameter) values, which remained fairly constant, with a slight decrease after the addition of rapeseed oil. These values are similar to those obtained for other emulsified edible films based on soya protein $(33,54,55)$ or gelatin $(56)$. A decrease in lightness values with the addition of lipid was also reported by Pereda et al. (20) for caseinate and tung oil edible films. The presence of rapeseed oil in whey protein matrix increased the green tone. Then, the parameter $a^{*}$ decreased and $b^{*}$ increased. Values of total colour difference $(\Delta E)$ increased significantly from 1.6 to 3.4 when increasing the volume fraction of rapeseed oil. These results were consistent with visual observations. The tendency of increasing values of total colour difference was obtained in soya protein or caseinate films containing vegetable oil $(18,20)$, but the values were higher, probably due to the higher fraction of added oil (5-20\% on dry basis). Similar observations were made in other protein films modified by the addition of different hydrophobic substances $(19,57)$. Taking into account that the colour parameters were obtained on a standard white plate, the decrease of $L^{*}$ and increase of $\Delta E$ values with respect to the control film reflect the decrease of transparency. Thus, the addition of the rapeseed oil contributes to the intensification of the colour of whey protein films, which is associated with its volume fraction. The investigated emulsified films were noticeably milky in comparison with pure whey films, which were transparent. Therefore, colour parameters should be taken into consideration since sensory aspects of coated products play an important role in consumer acceptability.
The emulsified films were much more opaque than control whey films, as can be observed by opacity values presented in Table 2. Droplets dispersed in the whey protein matrix affect the transparency by preventing light transmission through the film (32). Opacity values increased from 0.52 to $4.6 \mathrm{~mm}^{-1}$ with the increase of rapeseed oil content. The increase in opacity of films depending on the increasing content of lipids has been widely reported in the literature $(1,18,20,31,32,58)$. Villalobos et al. (53) and Monedero et al. (19) pointed out that the presence of a dispersed, non-miscible phase promotes opacity as a function of the differences in the refractive index of the phases and the concentration and particle size of the dispersed phase. According to Vargas et al. (59) the different transparency level should be linked to the internal structure development during drying when many changes occur. At the same time, the viscosity of the continuous phase increases, leading to creaming and coalescence during solvent evaporation.

\section{Sorption isotherms of films}

Fig. 2 shows the sorption isotherm plots (experimental points and Peleg's fitted equation) of whey protein films where the influence of the volume fraction of rapeseed oil and temperature on the moisture content and water activity can be observed. All curves were of similar shape, which is common for high-protein food absorbing a relatively small amount of water at low and a large amount of water at high $a_{\mathrm{w}}$. This shape of isotherms is characteristic for most biopolymer materials based on proteins, such as whey protein (60), sodium caseinate (61), soya protein (62) or gelatin (63). The equilibrium moisture contents of analyzed films increased slowly up to the $a_{\mathrm{w}}=0.50$, after which a small increase in humidity led to a large increase in equilibrium moisture content at constant temperature. This increase could be attributed to the fact that at low $a_{w}$, water is absorbed at the strongest binding sites of the surface of the solid. As $a_{\mathrm{w}}$ increases, the material swells, opening new sites for water to bind, resulting in the upswing of the profile. This behaviour was also observed by other researchers $(62,64-66)$. The addition of a plasticizer provides more active sites by exposing its hydrophilic hydroxyl groups on which water molecules can be adsorbed (67). Preparation of continuous whey protein films without a plasticizer was impossible; thus, all analyzed films contain glycerol, which as a hygroscopic substance affects moisture sorption isotherms. The incorporation of glycerol into protein films could improve their hydroscopic nature. This can be attributed to the effect of

Table 2. Opacity, $L^{*}, a^{*}$ and $b^{*}$ colour parameters, and total colour difference $(\Delta E)$ of whey protein films with different volume fractions of rapeseed oil

\begin{tabular}{|c|c|c|c|c|c|}
\hline$\varphi($ rapeseed oil $) / \%$ & Opacity $/ \mathrm{mm}^{-1}$ & $L^{*}$ & $a^{*}$ & $b^{*}$ & $\Delta E$ \\
\hline 0 & $(0.52 \pm 0.01)^{\mathrm{a}}$ & $(90.8 \pm 0.1)^{b}$ & $(0.91 \pm 0.03)^{\mathrm{b}}$ & $(-0.7 \pm 0.2)^{\mathrm{c}}$ & $(1.6 \pm 0.2)^{\mathrm{a}}$ \\
\hline 1 & $(2.5 \pm 0.3)^{\mathrm{b}}$ & $(89.9 \pm 0.2)^{\mathrm{a}}$ & $(0.95 \pm 0.06)^{\mathrm{b}}$ & $(-0.1 \pm 0.2)^{\mathrm{a}}$ & $(2.6 \pm 0.2)^{b}$ \\
\hline 2 & $(3.8 \pm 0.5)^{c}$ & $(89.9 \pm 0.2)^{\mathrm{a}}$ & $(0.81 \pm 0.07)^{\mathrm{a}}$ & $(-0.4 \pm 0.2)^{b}$ & $(3.0 \pm 0.2)^{\mathrm{b}}$ \\
\hline 3 & $(4.6 \pm 1.3)^{\mathrm{d}}$ & $(89.5 \pm 0.2)^{\mathrm{a}}$ & $(0.9 \pm 0.1)^{\mathrm{b}}$ & $(-0.2 \pm 0.2)^{\mathrm{a}}$ & $(3.4 \pm 0.2)^{\mathrm{c}}$ \\
\hline
\end{tabular}

The results are expressed as mean values with standard deviations. Different letters in superscript within the same column indicate significant differences between the films $(p<0.05)$ 

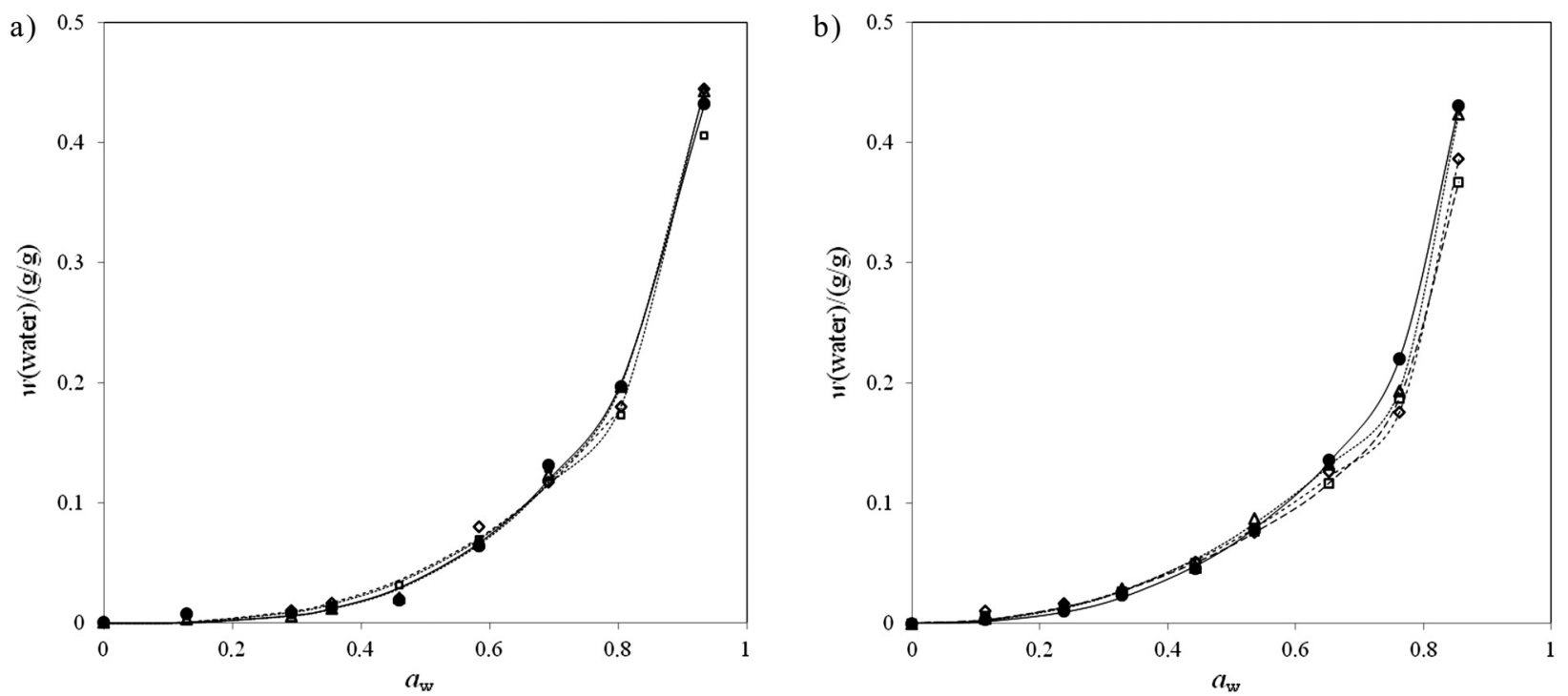

Fig. 2. Moisture sorption isotherms of whey protein films with different volume fractions of rapeseed oil, namely $0 \%(\bullet), 1 \%(\triangle), 2 \%$ $(\diamond)$, and $3 \%(\square)$ at: a) $5{ }^{\circ} \mathrm{C}$ and b) $25^{\circ} \mathrm{C}$. Experimental points and Peleg's fitted equation (lines)

solvent at determined $a_{\mathrm{w}}$ values, when low-molecular-mass polar solutes are present (61).

The addition of rapeseed oil to whey protein films reduced the water sorption only at $a_{\mathrm{w}}>0.8$ and $25^{\circ} \mathrm{C}$. It was observed that increasing the level of lipids decreased the equilibrium moisture content of the analyzed films. This is due to the hydrophobic nature of the rapeseed oil incorporated into whey protein films, which are mainly hydrophilic and have a higher water sorption capacity. The moisture content of whey films decreased due to the inclusion of rapeseed oil (Table 1), which was also reported for gelatin films with olive oil (1), quinoa protein and chitosan films with sunflower oil (10), and pistachio globulin protein films with fatty acids (68). Sorption isotherms with lower equilibrium moisture content caused by the presence of different lipids were observed in caseinate films (69), pullulan films (66), agar or cassava starch films (70), and alginate or carrageenan films (17). The incorporation of lipids reduces moisture sorption because lipids correspond to a fraction of solids with small water uptake capacity (69). Whey protein films were found to be sensitive to environmental humidity at high $a_{\mathrm{w}}$ values $(>0.8)$. The addition of rapeseed oil could reduce this effect, which is important considering the application of the films on the food surface and its storage time and temperature.

The effect of temperature on moisture sorption is of great importance since food products are not composed of an ideal mixture and their water activity changes with temperature (71). At constant $a_{\mathrm{w}}$, equilibrium moisture contents of analyzed whey protein films incorporated with rapeseed oil remained constant and did not change with an increase in temperature (Fig. 2). A decrease in equilibrium moisture content with an increase of temperature was reported in the literature for soya protein and cassava starch composite films (71), corn starch films (27) as well as for methylcellulose and ethylcellulose films (72). This behaviour may be explained by considering excitation state of molecules. As the temperature increases, the water molecules are activated due to an increase in their energy level, causing them to become less stable and to break away from the water-binding site of the food material, thus decreasing the monolayer water content (73). Usually, an increase in temperature causes a slight decrease in the solubility and an increase in the diffusion of water vapour through edible films (27).

Moisture sorption is used to determine the stability of the food material during storage and it depends on their chemical composition and structure (74). Water sorption isotherm equations are useful for predicting water sorption properties of biopolymer films and provide information about the driving potential for moisture migration. There are several mathematical models to describe water sorption isotherms of food materials. To be successful, any modelling equation should give as good a fit as possible to experimental data over a range of $a_{\mathrm{w}}$ using the minimum of adjustable parameters (60). In more recent years, the Guggenheim-Anderson-de Boer (GAB) isotherm equation has been widely used to describe the water sorption behaviour of hydrocolloid films $(60,64$, $66,75)$. This model was also used to fit experimental data for the complete $a_{\mathrm{w}}$ range with unsatisfactory results (data not shown). Parameters of the GAB equation did not fulfil the conditions presented by Lewicki (76). It has been shown that the GAB model describes well sigmoidal type isotherms when the parameters are maintained within the following limits: $0.24<k \leq 1$ and $5.67 \leq \mathrm{c} \leq \infty$, where $k$ and $c$ are GAB constants related to monolayer and multilayer properties, respectively. Outside these ranges the isotherm is either no longer sigmoidal or the monolayer capacity is estimated with an error larger than $\pm 15.5 \%$. Peleg's equation (28) has four adjustable parameters (A, B, C and $D)$, so it is expected to generally give a better fit than others. The high coefficient of determination $\left(R^{2}>0.998\right)$ confirmed the good fit of Peleg's equation to the experimental data (Table 3). Peleg's equation has been widely used to describe sorption isotherms for many products. Lewicki (77) applied this model to describe sorption iso- 
Table 3. Peleg's equation parameters and determination coefficient $\left(\mathrm{R}^{2}\right)$ obtained from moisture sorption isotherms of whey protein films with the addition of rapeseed oil at different temperatures

\begin{tabular}{|c|c|c|c|c|c|c|c|c|c|c|}
\hline \multirow{3}{*}{$\varphi($ rapeseed oil $) / \%$} & \multicolumn{10}{|c|}{$t /{ }^{\circ} \mathrm{C}$} \\
\hline & \multicolumn{5}{|c|}{5} & \multicolumn{5}{|c|}{25} \\
\hline & A & B & $\mathrm{C}$ & $\mathrm{D}$ & $\mathrm{R}^{2}$ & A & B & $\mathrm{C}$ & $\mathrm{D}$ & $\mathrm{R}^{2}$ \\
\hline 0 & 1.288 & 37.69 & 0.422 & 3.417 & 0.998 & 2.932 & 18.73 & 0.417 & 2.666 & 0.999 \\
\hline 1 & 1.097 & 33.38 & 0.419 & 3.446 & 0.999 & 18.180 & 29.53 & 0.354 & 2.316 & 0.999 \\
\hline 2 & 2.664 & 40.99 & 0.347 & 2.977 & 0.998 & 22.173 & 31.24 & 0.310 & 2.178 & 0.999 \\
\hline 3 & 2.013 & 39.82 & 0.332 & 2.857 & 0.998 & 1.763 & 15.13 & 0.282 & 2.112 & 0.999 \\
\hline
\end{tabular}

therms for 27 products. He demonstrated that the highest probability of fitting experimental data with the minimum mean relative error is guaranteed by Peleg's model. This model has also been used to describe sorption isotherms of whey films (60) as well as of other hydrocolloid films, e.g. cassava flour films (78), pectin films (79) and alginate and pectin blend films (22).

\section{Mechanical properties of films}

Mechanical properties of edible films are important to ensure that the film has adequate mechanical strength and integrity during transportation, handling and storage of foods coated with them (40). Tensile strength indicates the maximum tensile stress that the film can sustain, Young's modulus is a measure of the stiffness of the film, and elongation at break is the maximum change in length of a test specimen before breaking (32). Table 4 shows the tensile parameters of whey protein films with rapeseed oil. The addition of oil had a significant effect $(p<0.01)$ on the increase of tensile strength values and elongation at break; the greater the content of lipids, the higher the values of parameters. Lower values of Young's modulus were observed when 1 or $2 \%$ of oil was added and the highest value was reached with the highest oil volume fraction $(3 \%)$. This means that incorporation of a relatively low amount (1-3\%) of liquid lipids into the whey protein matrix leads to more compact structure, with increasing continuities within the protein network. This effect can be attributed to the development of discontinuities in the polymer network resulting from the lipid addition. Furthermore, the increase in elongation can probably be attributed to the plasticizing effect of oil in the protein matrix. An increase in elongation at break of whey films modified with the addition of soya oil was previously reported $(31,80)$. The increase in all tensile parameters of

Table 4. Tensile strength (TS), Young's modulus (YM) and elongation at break $\left(\varepsilon_{\mathrm{b}}\right)$ of whey protein films with different volume fractions of rapeseed oil

\begin{tabular}{cccc}
\hline$\varphi$ (rapeseed oil)/\% & TS/MPa & YM/MPa & $\varepsilon_{\mathrm{b}} / \%$ \\
\hline 0 & $(4.9 \pm 0.7)^{\mathrm{a}}$ & $(23.6 \pm 4.5)^{\mathrm{b}}$ & $(34.4 \pm 4.6)^{\mathrm{a}}$ \\
1 & $(4.3 \pm 0.5)^{\mathrm{b}}$ & $(16.9 \pm 1.9)^{\mathrm{a}}$ & $(43.7 \pm 8.3)^{\mathrm{b}}$ \\
2 & $(5.9 \pm 0.2)^{\mathrm{c}}$ & $(20.1 \pm 3.7)^{\mathrm{ab}}$ & $(45.9 \pm 3.3)^{\mathrm{b}}$ \\
3 & $(6.3 \pm 0.3)^{\mathrm{c}}$ & $(31.5 \pm 5.6)^{\mathrm{c}}$ & $(73.1 \pm 4.4)^{\mathrm{c}}$ \\
\hline
\end{tabular}

The results are expressed as mean values with standard deviations. Different letters in superscript within the same column indicate significant differences between the films $(p<0.05)$ emulsified films based on gelatin and olive oil (1) or chitosan and olive oil was previously reported (32). The authors explained those observations by the strong interaction between the polymer and the lipid particles as a crosslinking effect, which decreased the free volume and the molecular mobility of the polymer.

In general, films containing lipids lack the structural integrity of protein or polysaccharide films (81). Therefore, incorporation of lipids into hydrophilic protein films in an effort to decrease their barrier properties can negatively affect film strength, which was confirmed by tensile strength measurements. Most authors found that the inclusion of different lipids including waxes $(42,82)$ and an acetylated monoglyceride (83) impaired the mechanical properties of emulsion films in comparison with the control whey protein films. Nevertheless, differences in tensile parameters of emulsified films depend strongly on the lipid type and film composition.

\section{Film microstructure}

All films were flexible and easy to handle, without pores or cracks. Control film was transparent and those containing rapeseed oil were opaque. Small losses of lipids after the removal of the films from the plate were observed. The appearance of both sides of the film was different, with an oily upper surface and a dry, shiny lower surface. Similar observations were observed in the literature for biopolymer films containing lipids $(21,31,58)$. Fig. 3 shows scanning electron micrographs of the upper surface and cross section of the films of both control and rapeseed oil-containing films. Emulsion films had a rough and uneven surface, whereas in the absence of rapeseed oil, whey protein film had a smooth, homogeneous surface. These structural discontinuities in lipid-containing films were due to the lack of miscibility of the components. The protein matrix seems to be interrupted by oil droplets. Both surface and cross section micrographs of the emulsion films showed that the dispersed lipid phase creamed, forming an apparent bilayer structure with most lipid droplets on the upper surface of the films. It has also been demonstrated that emulsion-based film structure depends on the lipid content. An increasing amount of rapeseed oil droplets resulted in a larger lipid layer on the evaporation front, leading to an increase in the roughness of the film structure. This difference could affect some surface-related properties of the films, such as water adsorption or optical parameters. The aggregation of oil droplets during film drying is obvious in micrographs. Furthermore, irregular lipid masses embedded on the film surface occurred when films contained 1 and $2 \%$ 
a)

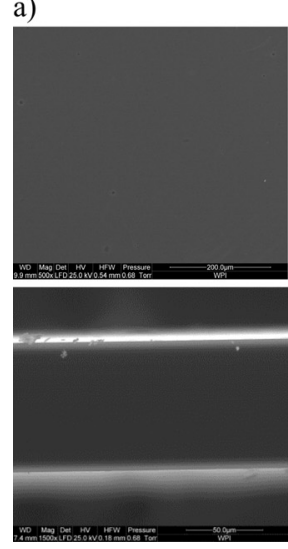

b)

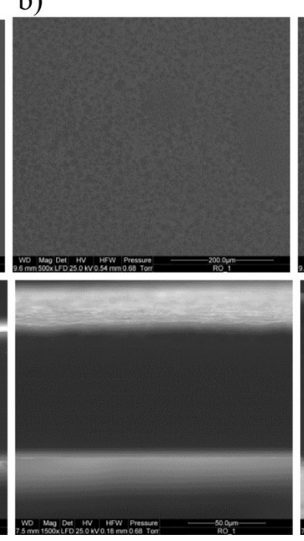

c)

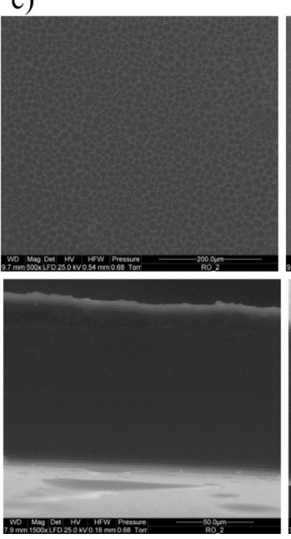

d)

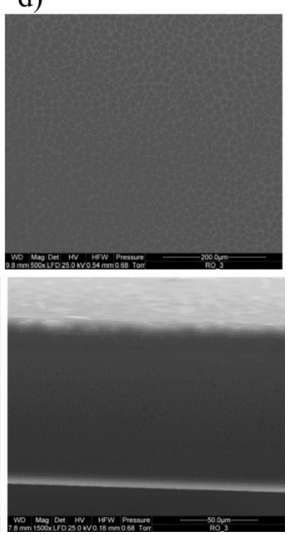

Fig. 3. Scanning electron micrographs of the surface (magnification $500 \times$, upper row) and cross sections (magnification $1500 \times$, bottom row) of whey protein films with different volume fractions of rapeseed oil: a) $0 \%, b) 1 \%$, c) $2 \%$ and d) $3 \%$

of rapeseed oil, whose droplet size was bigger according to particle size measurement. Aggregation and coalescence phenomena start immediately after homogenization in the absence of emulsifiers and occur during drying of emulsified solutions (35). Formation of lipid droplets and their development during film drying entail the interruption of the polymer matrix, increasing the internal heterogeneity and surface roughness of the film $(53,61)$. Whey proteins play a great role in the stabilization of the emulsion by formation of a stabilizing layer around fat droplets. This indicates that whey protein should be able to form a protective film around fat droplets during homogenization, and long-term emulsion stability is conferred by homogeneous fat distribution within the film. However, a creaming effect was observed in this study caused by migration of a lipid fraction towards the evaporation surface of the film. Similar observations were reported for other biopolymer films containing lipids $(1,39,61,70)$. This increasing surface hydrophobicity due to the presence of lipid globules can enhance moisture sorption and water vapour mobility by increasing the polarity of the films. Therefore, composite films made from both hydrocolloids and lipids may have advantages connected with selective migration of water molecules or active compounds when they are used as a coating on food products.

\section{Conclusions}

Whey protein emulsion films incorporated with rapeseed oil at low volume fractions were successfully prepared and characterized. The presence of rapeseed oil leads to changes in the structure of protein films that influence the water affinity of the films, changing their properties. Thus, water solubility is expected to be a decreasing function of temperature. It should be noted that moisture content at higher water activity values $\left(a_{\mathrm{w}}>0.6\right)$ starts to increase exponentially, producing film structural changes that allow a facilitated water transport phenomenon. At constant $a_{\mathrm{w}}$ equilibrium moisture contents of analyzed whey protein films incorporated with rapeseed oil remained constant and did not change with an increase in temperature. A different internal arrangement was observed in the cross section of films as a function of film composition. Experiments showed that the change in the composition of whey protein films with rapeseed oil would not affect greatly the appearance of food products when in use. Addition of rapeseed oil could reduce moisture sensitivity, which would be especially important in the application of the films for the protection of products with high moisture content.

\section{Acknowledgements}

This work was financially supported by the Ministry of Science and Higher Education, Poland, through IUVENTUS PLUS Project IP2011 013371. The authors acknowledge Dr Leszek Hejduk from the Division of River Engineering (Faculty of Civil and Environmental Engineering, WULS-SGGW, Warsaw, Poland) for his helpful assistance when carrying out particle size measurements.

\section{References}

1. Ma W, Tang $\mathrm{CH}$, Yin SW, Yang XQ, Wang Q, Liu F, Wei ZH. Characterization of gelatin-based edible films incorporated with olive oil. Food Res Int. 2014;49:572-9. http://dx.doi.org/10.1016/j.foodres.2012.07.037

2. Gontard N, Duchez C, Cuq JL, Guilbert S. Edible composite films of wheat gluten and lipids: water vapour permeability and other physical properties. Int J Food Sci Technol. 1994;29:39-50.

http://dx.doi.org/10.1111/j.1365-2621.1994.tb02045.x

3. Kokoszka S, Debeaufort F, Lenart A, Voilley A. Water vapor permeability, thermal and wetting properties of whey protein isolate based edible films. Int Dairy J. 2010;20:53-60. http://dx.doi.org/10.1016/j.idairyj.2009.07.008

4. Soliman EA, Tawfik MS, El-Sayed H, Moharram YG. Preparation and characterization of soy protein based edible/biodegradable films. Am J Food Technol. 2007;2:462-76. http://dx.doi.org/10.3923/ajft.2007.462.476

5. Fabra MJ, Talens P, Chiralt A. Tensile properties and water vapor permeability of sodium caseinate films containing oleic acid-beeswax mixtures. J Food Eng. 2008;85:393-400. http://dx.doi.org/10.1016/j.jfoodeng.2007.07.022

6. Deiber JA, Peirotti MB, Ottone ML. Rheological characterization of edible films made from collagen colloidal particle suspensions. Food Hydrocolloid. 2011;25:1382-92. http://dx.doi.org/10.1016/j.foodhyd.2011.01.002

7. Vanin FM, Sobral PJA, Menegalli FC, Carvalho RA, Habit- 
ante AMQB. Effects of plasticizers and their concentrations on thermal and functional properties of gelatin-based films. Food Hydrocolloid. 2005;19:899-907.

http://dx.doi.org/10.1016/j.foodhyd.2004.12.003

8. Cho SY, Lee SY, Rhee C. Edible oxygen barrier bilayer films pouches from corn zein and soy protein isolate for olive oil packaging. LWT - Food Sci Technol. 2010;43:1234-9. http://dx.doi.org/10.1016/j.lwt.2010.03.014

9. Giménez B, Gómez-Guillén MC, López-Caballero ME, Gómez-Estaca J, Montero P. Role of sepiolite in the release of active compounds from gelatin-egg white films. Food Hydrocolloid. 2012;27:475-86.

http://dx.doi.org/10.1016/j.foodhyd.2011.09.003

10. Valenzuela C, Abugoch L, Tapia C. Quinoa protein-chitosansunflower oil edible film: mechanical, barrier and structural properties. J Food Sci Technol. 2013;50:531-7. http://dx.doi.org/10.1016/j.lwt.2012.08.010

11. Cuq B, Gontard N, Cuq JL, Guilbert S. Functional properties of myofibrillar protein-based biopackaging as affected by film thickness. J Food Sci. 1996;61:580-4. http://dx.doi.org/10.1111/j.1365-2621.1996.tb13163.x

12. Wihodo M, Moraru CI. Physical and chemical methods used to enhance the structure and mechanical properties of protein films: a review. J Food Eng. 2013;114:292-302. http://dx.doi.org/10.1016/j.jfoodeng.2012.08.021

13. Khwaldia K, Perez C, Banon S, Desobry S, Hardy J. Milk protein for edible films and coatings. Crit Rev Food Sci Nutr. 2004;44:239-51.

http://dx.doi.org/10.1080/10408690490464906

14. Kurek M, Galus S, Debeaufort F. Surface, mechanical and barrier properties of bio-based composite films based on chitosan and whey protein. Food Packaging Shelf Life. 2014;1:56-67.

http://dx.doi.org/10.1016/j.fpsl.2014.01.001

15. Galietta G, Di Gioia L, Guilbert S, Cuq B. Mechanical and thermomechanical properties of films based on whey proteins as affected by plasticizer and crosslinking agents. J Dairy Sci. 1998;81:3123-30. http://dx.doi.org/10.3168/jds.S0022-0302(98)75877-1

16. Guilbert $\mathrm{S}$. Technology and application of edible protective films. In: Mathlouthi M, editor. Food packaging and preservation: Theory and practice. New York, NY, USA: Elsevier Applied Science Publishers; 1986. pp. 371-94.

17. Hambleton A, Perpiñan-Saiz N, Fabra MJ, Voilley A, Debeaufort F. The Schroeder paradox or how the state of water affects the moisture transfer through edible films. Food Chem. 2012;132:1671-8. http://dx.doi.org/10.1016/j.foodchem.2011.03.009

18. Guerrero P, Nur Hanani ZA, Kerry JP, de la Caba K. Characterization of soy protein-based films prepared with acids and oils by compression. J Food Sci. 2011;107:41-9. http://dx.doi.org/10.1016/j.jfoodeng.2011.06.003

19. Monedero FM, Fabra MJ, Talens P, Chiralt A. Effect of oleic acid-beeswax mixtures on mechanical, optical and water barrier properties of soy protein isolate based films. J Food Eng. 2009;91:509-15. http://dx.doi.org/10.1016/j.jfoodeng.2008.09.034

20. Pereda M, Aranguren MI, Marcovich NE. Caseinate films modified with tung oil. Food Hydrocolloid. 2010;24:800-8. http://dx.doi.org/10.1016/j.foodhyd.2010.04.007

21. Kokoszka S, Debeaufort F, Lenart A, Voilley A. Liquid and vapour water transfer through whey protein/lipid emulsion films. J Sci Food Agric. 2010;90:1673-80. http://dx.doi.org/10.1002/jsfa.4001

22. Galus S, Lenart A. Development and characterization of composite edible films based on sodium alginate and pectin.
J Food Eng. 2013;115:459-65.

http://dx.doi.org/10.1016/j.jfoodeng.2012.03.006

23. Rhim JW, Gennadios A, Weller CL, Cezeirat C, Hanna MA Soy protein isolate-dialdehyde starch films. Ind Crops Prod. 1998;8:195-203. http://dx.doi.org/10.1016/S0926-6690(98)00003-X

24. Cao N, Fu Y, He J. Preparation and physical properties of soy protein isolate and gelatin composite films. Food Hydrocolloid. 2007;21:1153-62.

http://dx.doi.org/10.1016/j.foodhyd.2006.09.001

25. Han JH, Floros JD. Casting antimicrobial packaging films and measuring their physical properties and antimicrobial activity. J Plast Film Sheet. 1997;13:287-98. http://dx.doi.org/10.1177/875608799701300405

26. Sobral PJA, dos Santos JS. García FT. Effect of protein and plasticizer concentration in film forming solutions on physical properties of edible films based on muscle proteins of a Thai tilapia. J Food Eng. 2005;70:93-100. http://dx.doi.org/10.1016/j.jfoodeng.2004.09.015

27. Bertuzzi MA, Castro Vidaurre EF, Armada M, Gottifredi JC. Water vapor permeability of edible starch based films. J Food Eng. 2007;80:972-8. http://dx.doi.org/10.1016/j.jfoodeng.2006.07.016

28. Peleg M. Assessment of a semi-empirical four parameter general model for sigmoid moisture sorption isotherms. J Food Process Eng. 1993;16:21-37.

http://dx.doi.org/10.1111/j.1745-4530.1993.tb00160.x

29. ASTM D882-02. Standard test methods for tensile properties of thin plastic sheeting. West Conshohocken, PA, USA: ASTM International; 2002.

30. Pérez-Gago MB, Krochta JM. Lipid particle size effect on water vapor permeability and mechanical properties of whey protein-beeswax emulsion films. J Agric Food Chem. 2001;49:996-1002. http://dx.doi.org/10.1021/jf000615f

31. Shaw NB, Monahan FJ, O'Riordan ED, O'Sullivan M. Effect of soya oil and glycerol on physical properties of composite WPI films. J Food Eng. 2002;51:299-304. http://dx.doi.org/10.1016/S0260-8774(01)00071-1

32. Pereda M, Amica G, Marcovich NE. Development and characterization of edible chitosan/olive oil emulsion films. Carbohydr Polym. 2012;87:1318-25. http://dx.doi.org/10.1016/j.carbpol.2011.09.019

33. Atarés L, De Jesús C, Talens P, Chiralt A. Characterization of SPI-based edible films incorporated with cinnamon or ginger essential oils. J Food Eng. 2010;99:384-91. http://dx.doi.org/10.1016/j.jfoodeng.2010.03.004

34. Pérez-Gago MB, Krochta JM. Drying temperature effect on water vapor permeability and mechanical properties of whey protein-lipid emulsion films. J Agric Food Chem. 2000;48: 2687-92. http://dx.doi.org/10.1021/jf0001583

35. Karbowiak T, Debeaufort F, Voilley A. Influence of thermal process on structure and functional properties of emulsionbased edible films. Food Hydrocolloid. 2007;21:879-88. http://dx.doi.org/10.1016/j.foodhyd.2006.07.017

36. Langton $\mathrm{M}$, Hermansson AM. Image analysis determination of particle size distribution. Food Hydrocolloid. 1993;7:1122. http://dx.doi.org/10.1016/S0268-005X(09)80021-0

37. Sánchez-Gónzalez L, Cháfer M, Chiralt A, González-Martínez C. Physical properties of edible chitosan films containing bergamot essential oil and their inhibitory action on Penicillium italicum. Carbohydr Polym. 2010;82:277-83. http://dx.doi.org/10.1016/j.carbpol.2010.04.047

38. Bonilla J, Atarés L, Vargas M, Chiralt A. Effect of essential oils and homogenization conditions on properties of chito- 
san-based films. Food Hydrocolloid. 2012;26:9-16.

http://dx.doi.org/10.1016/j.foodhyd.2011.03.015

39. Zúñiga RN, Skurtys O, Osorio F, Aguilera JM, Pedreschi F. Physical properties of emulsion-based hydroxypropyl methylcellulose films: effect of their microstructure. Carbohydr Polym. 2012;90:1147-58.

http://dx.doi.org/10.1016/j.carbpol.2012.06.066

40. Ozdemir M, Floros JD. Optimization of edible whey protein films containing preservatives for mechanical and optical properties. J Food Eng. 2008;84:116-23. http://dx.doi.org/10.1016/j.jfoodeng.2007.04.029

41. Pérez-Gago MB, Nadaud P, Krochta JM. Water vapor permeability, solubility, and tensile properties of heat-denatured versus native whey protein films. J Food Sci. 1999;64:1034-7. http://dx.doi.org/10.1111/j.1365-2621.1999.tb12276.x

42. Soazo M, Rubiolo AC, Verdini RA. Effect of drying temperature and beeswax content on physical properties of whey protein emulsion films. Food Hydrocolloid. 2011;25:1251-5. http://dx.doi.org/10.1016/j.foodhyd.2010.11.022

43. Cerqueira MA, Souza BWS, Teixeira JA, Vicente AA. Effect of glycerol and corn oil on physicochemical properties of polysaccharide films - a comparative study. Food Hydrocolloid. 2012;27:175-84. http://dx.doi.org/10.1016/j.foodhyd.2011.07.007

44. Soazo M, Pérez LM, Rubiolo AC, Verdini RA. Effect of freezing on physical properties of whey protein emulsion films. Food Hydrocolloid. 2013;31:256-63. http://dx.doi.org/10.1016/j.foodhyd.2012.10.022

45. Chiumarelli M, Hubinger MD. Evaluation of edible films and coatings formulated with cassava starch, glycerol, carnauba wax and stearic acid. Food Hydrocolloid. 2014;38:2027. http://dx.doi.org/10.1016/j.foodhyd.2013.11.013

46. McHugh TH, Krochta JM. Milk protein based edible films and coatings. Food Technol. 1994;48:97-103.

47. Müller CMO, Yamashita F, Laurindo JB. Evaluation of the effects of glycerol and sorbitol concentration and water activity on the water barrier properties of cassava starch films through a solubility approach. Carbohydr Polym. 2008;72: $82-7$. http://dx.doi.org/10.1016/j.carbpol.2007.07.026

48. Razavi SMA, Amini AM, Zahedi Y. Characterisation of a new biodegradable edible film based on sage seed gum: Influence of plasticiser type and concentration. Food Hydrocolloid. 2015;43:290-8. http://dx.doi.org/10.1016/j.foodhyd.2014.05.028

49. Ahmadi R, Kalbasi-Ashtari A, Oromiehie A, Yarmand MS, Jahandideh F. Development and characterization of a novel biodegradable edible film obtained from psyllium seed (Plantago ovata Forsk). J Food Eng. 2012;109:745-51. http://dx.doi.org/10.1016/j.jfoodeng.2011.11.010

50. Di Pierro P, Chico B, Villalonga R, Mariniello L, Damiao AE, Masi P, Porta R. Chitosan-whey protein edible films produces in the absence or presence of transglutaminase: analysis of their mechanical and barrier properties. Biomacromolecules. 2006;7:744-9. http://dx.doi.org/10.1021/bm050661u

51. Hernandez-Munõz P, López-Rubio A, del-Valle V, Almenar E, Gavara R. Mechanical and water barrier properties of gluten films influenced by storage time. J Agric Food Chem. 2004;52:79-83. http://dx.doi.org/10.1021/jf034763s

52. Rhim JW, Gennadios A, Weller CL, Hanna MA. Sodium dodecyl sulfate treatment improves properties of cast films from soy protein isolate. Ind Crops Prod. 2002;15:199-205. http://dx.doi.org/10.1016/S0926-6690(01)00114-5

53. Villalobos R, Chanona J, Hernández P, Gutiérrez G, Chiralt
A. Gloss and transparency of hydroxypropil methylcellulose films containing surfactants as affected by their microstructure. Food Hydrocolloid. 2005;19:53-61.

http://dx.doi.org/10.1016/j.foodhyd.2004.04.014

54. Pruneda E, Peralta-Hernández JM, Esquivel K, Lee SY, Godínez LA, Mendoza S. Water vapor permeability, mechanical properties and antioxidant effect of Mexican oregano-soy based edible films. J Food Sci. 2008;73:488-93. http://dx.doi.org/10.1111/j.1750-3841.2008.00843.x

55. Monedero FM, Fabra MJ, Talens P, Chiralt A. Effect of calcium and sodium caseinates on physical characteristics of soy protein isolate-lipid films. J Food Eng. 2010;97:228-34. http://dx.doi.org/10.1016/j.jfoodeng.2009.10.014

56. Bao S, Xu S, Wang Z. Antioxidant activity and properties of gelatin films incorporated with tea polyphenol-loaded chitosan nanoparticles. J Sci Food Agric. 2009;89:2692-700. http://dx.doi.org/10.1002/jsfa.3775

57. Pires C, Ramos C, Teixeira B, Batista I, Nunes ML, Marques A. Hake protein edible films incorporated with essential oils: physical, mechanical, antioxidant and antimicrobial properties. Food Hydrocolloid. 2013;30:224-31. http://dx.doi.org/10.1016/j.foodhyd.2012.05.019

58. Yang L, Paulson AT. Mechanical and water vapor barrier properties of edible gellan films. Food Res. Int. 2000;33:56370 . http://dx.doi.org/10.1016/S0963-9969(00)00092-2

59. Vargas M, Albors A, Chiralt A, González-Martínez C. Characterization of chitosan-oleic acid composite films. Food Hydrocolloid. 2009;23:536-47. http://dx.doi.org/10.1016/j.foodhyd.2008.02.009

60. Coupland JN, Shaw NB, Monahan FJ, O'Riordan ED, O'Sullivan M. Modeling the effect of glycerol on the moisture sorption behavior of whey protein edible films. J Food Eng. 2000;43:25-30.

http://dx.doi.org/10.1016/S0260-8774(99)00129-6

61. Fabra MJ, Talens P, Chiralt A. Microstructure and optical properties of sodium caseinate films containing oleic acidbeeswax mixture. Food Hydrocolloid. 2009;23:679-83. http://dx.doi.org/10.1016/j.foodhyd.2008.04.015

62. Cho SY, Rhee C. Sorption characteristics of soy protein films and their relation to mechanical properties. LWT - Food Sci Technol. 2002;35;151-7. http://dx.doi.org/10.1006/fstl.2001.0829

63. Lim LT, Mine Y, Tung MA. Barrier and tensile properties of transglutaminase cross-linked gelatin films as affected by relative humidity, temperature and glycerol content. J Food Sci. 1999;64:616-20. http://dx.doi.org/10.1111/j.1365-2621.1999.tb15096.x

64. Jangchud A, Chinnan MS. Properties of peanuts protein films: sorption isotherm andplasticizereffect. LWT - Food Sci Technol. 1999;32:89-94.

http://dx.doi.org/10.1006/fstl.1998.0498

65. Osés J, Fabregat-Vázquez M, Pedroza-Islas R, Tomás SA, Cruz-Orea A, Maté JI. Development and characterization of composite edible films based on whey protein isolate and mesquite gum. J Food Eng. 2009;92:56-62. http://dx.doi.org/10.1016/j.jfoodeng.2008.10.029

66. Shih FF, Daigle KW, Champagne ET. Effect of wax on water vapour permeability and sorption properties of edible pullulan films. Food Chem. 2011;127:118-21.

http://dx.doi.org/10.1016/j.foodchem.2010.12.096

67. Mali S, Sakanaka LS, Yamashita F, Grossmann MVE. Water sorption and mechanical properties of cassava starch films and their relation to plasticizing effect. Carbohydr Polym. 2005;60:283-9.

http://dx.doi.org/10.1016/j.carbpol.2005.01.003

68. Zahedi Y, Ghanbarzadeh B, Sedaghat N. Physical properties 
of edible emulsified films based on pistachio globulin protein and fatty acids. J Food Eng. 2010;100:102-8. http://dx.doi.org/10.1016/j.jfoodeng.2010.03.033

69. Fabra MJ, Talens P, Chiralt A. Water sorption isotherms and phase transitions of sodium caseinate-lipid films as affected by lipid interactions. Food Hydrocolloid. 2010;24:384-91. http://dx.doi.org/10.1016/j.foodhyd.2009.11.004

70. Phan The D, Debeaufort F, Voilley A, Luu D. Influence of hydrocolloid nature on the structure and functional properties of emulsified edible films. Food Hydrocolloid. 2009;23:6919. http://dx.doi.org/10.1016/j.foodhyd.2008.05.006

71. Chinma CE, Ariahu CC, Alakali J. Moisture sorption and thermodynamic properties of cassava starch and soy protein concentrate based edible films. Int J Food Sci Technol. 2013;48:2400-7. http://dx.doi.org/10.1111/ijfs.12231

72. Velázquez de la Cruz G, Torres JA, Martín-Polo MO. Temperature effect on the moisture sorption isotherms for methylcellulose and ethylcellulose films. J Food Eng. 2001;48:914. http://dx.doi.org/10.1016/S0260-8774(00)00143-6

73. Jamali A, Kouhila M, Ait Mohamed L, Idlimam A, Lamharrar A. Moisture adsorption-desorption isotherms of Citrus reticulata leaves at three temperatures. J Food Eng. 2006;77:71-8 http://dx.doi.org/10.1016/j.jfoodeng.2005.06.045

74. Ciurzyńska A, Piotrowski D, Lenart A, Łukasik P. Sorption properties of vacuum-dried strawberries. Dry Technol. 2012;30:850-8. http://dx.doi.org/10.1080/07373937.2012.668999

75. Xiao Q, Tong $\mathrm{Q}$. Thermodynamic properties of moisture sorption in pullulan-sodium alginate edible films. Food Res
Int. 2013;54:1605-12.

http://dx.doi.org/10.1016/j.foodres.2013.09.019

76. Lewicki PP. The applicability of the GAB model to food water sorption isotherms. Int J Food Sci Technol. 1997;32:553-7. http://dx.doi.org/10.1111/j.1365-2621.1997.tb02131.x

77. Lewicki PP. A three parameter equation for food moisture isotherms. J Food Eng. 1998;21:127-44. http://dx.doi.org/10.1111/j.1745-4530.1998.tb00444.x

78. Suppakul P, Chalernsook B, Ratisuthawat B, Prapasitthi S, Munchukangwan N. Empirical modeling of moisture sorption characteristics and mechanical and barrier properties of cassava flour film and their relation to plasticizing-antiplasticizing effects. LWT - Food Sci Technol. 2013;50:290-7. http://dx.doi.org/10.1016/j.lwt.2012.05.013

79. Galus G, Turska A, Lenart A. Sorption and wetting properties of pectin edible films. Czech J Food Sci. 2012;30:446-55.

80. Fang Y, Tung MA, Britt IJ, Yada S, Dalgleish DG. Tensile and barrier properties of edible films made from whey proteins. J Food Sci. 2002;67:188-93. http://dx.doi.org/10.1111/j.1365-2621.2002.tb11381.x

81. Gontard N, Marchesseau S, Cuq JL, Guilbert S. Water vapor permeability of edible bilayer films of wheat gluten and lipids. Int J Food Sci Technol. 1995;30:49-56.

http://dx.doi.org/10.1111/j.1365-2621.1995.tb01945.x

82. Shellhammer TH, Krochta JM. Whey protein emulsion film performances as affected by lipid type and amount. J Food Sci. 1997;62:390-4. http://dx.doi.org/10.1111/j.1365-2621.1997.tb04008.x

83. Anker M, Bernsten J, Hermansson AM, Stading M. Improved water vapor barrier of whey protein films by addition of an acetylated monoglyceride. Innov Food Sci Emerg Technol. 2002;3:81-92. http://dx.doi.org/10.1016/S1466-8564(01)00051-0 